\title{
Eyes Absent Homolog 1
}

National Cancer Institute

\section{Source}

National Cancer Institute. Eyes Absent Homolog 1. NCI Thesaurus. Code C75392.

Eyes absent homolog 1 (592 aa, $65 \mathrm{kDa}$ ) is encoded by the human EYA1 gene. This protein may play a role in embryonic development. 